DOI: http://dx.doi.org/10.33846/hn40701

http://heanoti.com/index.php/hn

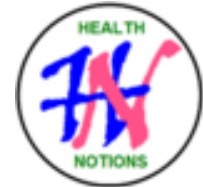

RESEARCH ARTICLE

URL of this article: http://heanoti.com/index.php/hn/article/view/hn40701

\title{
Effectiveness of Strawberry Extract with $100 \%$ Concentration in Cleaning Teeth with Extrinsic Stain at the Academic Community of Poltekkes Kemenkes Jakarta I
}

\author{
Ita Astit Karmawati $^{1(\mathrm{CA})}$, Ita Yulita ${ }^{2}$, Rahaju Budiarti ${ }^{3}$, Syifa Yulia Lestari $^{4}$ \\ ${ }^{1(\mathrm{CA})}$ Poltekkes Kemenkes Jakarta I, Indonesia; itaastit@yahoo.com (Corresponding Author) \\ ${ }^{2}$ Poltekkes Kemenkes Jakarta I, Indonesia; iyulita67@yahoo.com \\ ${ }^{3}$ Poltekkes Kemenkes Jakarta I, Indonesia; rahayu.budiarti13@gmail.com \\ ${ }^{4}$ Poltekkes Kemenkes Jakarta I, Indonesia; syifa_yulia95@yahoo.co.id4
}

\begin{abstract}
Discoloration of teeth can be caused by stains on the surface of the teeth or due to changes in tooth material. Tooth stain can be extrinsic, intrinsic, or age-related. Tooth whitening (bleaching) can be done in the office and at home. Strawberry is a fruit with many benefits, one of which is whitening teeth. The content of malic acid and ellagic acid in strawberries has the effect of tooth whitening. The purpose of this study was to determine the effectiveness of strawberry extract with a concentration of $100 \%$ in cleaning teeth with the extrinsic stain on an academic member of the Health Polytechnic Jakarta I. This study was an experiment on 31 people who had upper and lower anterior teeth with the extrinsic stain as samples. Data collection was done by applying strawberry extract with a concentration of $100 \%$ on the surface of the anterior teeth, allowed to stand for 5 minutes, then brushed and rinsed with water. This procedure was done 2 times a day for 5 consecutive days. Changes in extrinsic stain were measured using the Lobene Stain Index which measures the intensity and area of the stain, as well as a combined score of both. The average combined score with measurements using the Lobene Stain Index for extrinsic stain before being treated with strawberries was 22.4. The score has decreased every day starting from day 1 to day 5 of treatment. The largest decrease of the average Combined Score was occurred on the 2 nd day, namely from a score of 20.0 on the 1st day to 14.6 on the 2nd day with a percentage reduction of $35.0 \%$. Statistical tests showed significant results of 0,000 reducing the Intensity Score and Area Score on day 2 to day 5 . It can be concluded that there was a significant decrease in extrinsic stain scores after treatment on day 2 .
\end{abstract}

Keywords: extrinsic stain; strawberry extract

\section{INTRODUCTION}

\section{Background}

The color of one's teeth is varies, but different colors prominently it will certainly be very annoying and now it is starting to get the attention of both the public and dentists. ${ }^{(1)}$ Teeth whitening by dentists is termed as in-office bleaching, whereas what is done at home is referred to as at-home bleaching. ${ }^{(2)}$ One of the ingredients used to whiten teeth is Hydrogen Peroxide $\left(\mathrm{H}_{2} \mathrm{O}_{2}\right)$ and Carbamide Peroxide. $10 \%$ of Hydrogen Peroxide is the same as Carbamide Peroxide 2\%. However, in other research, the use of Carbamide Peroxide $2 \% 60$ seconds a day for 3 days alone can significantly cause inflammation of the oral mucosa. ${ }^{(3)}$

Strawberry has long been known to have many benefits including malic acid contained in strawberries acts as a substance that will erode and remove some stains on the surface of the teeth. ${ }^{(4)}$ Research conducted by Adawiyah $\mathrm{R}^{(5)}$ concluded that strawberries can be used as extrinsic teeth whitening ingredients, whereas our previous study. ${ }^{(6)}$ also concluded that the application of strawberries can change the color of teeth to be brighter, 
and other studies ${ }^{(7)}$ have shown that strawberries can clean an extrinsic stain.

\section{Purpose}

Based on the background, the researchers are interested in conducting further experiments in the form of how effective the extract of strawberries in cleaning the surface of the teeth with an extrinsic stain on the member of academic community of Health Polytechnic Jakarta I. This study intends to find the effectiveness of strawberry extract with a concentration of $100 \%$ in cleaning the extrinsic stain.

\section{METHODS}

The research was carried out through several stages which included: testing the effect of the application of strawberries in cleaning stains on avulsion teeth in the laboratory (in vitro study in 2014). Followed by testing the effect of the application of strawberries in cleaning stains on teeth that are still in the mouth (done in 2015). The next stage was testing the effectiveness of strawberry extracts with concentrations of $100 \%, 75 \%, 50 \%$, and $25 \%$ to remove tooth stain on teeth that have been avulsed in the laboratory (in vitro in 2017); and this stage which testing the effectiveness of removing tooth stain using strawberry fruit extract with a concentration of $100 \%$ on teeth in humans. Since we use teeth in the human mouth, we have an ethical exemption in accordance with 7 (seven) WHO 2011 Standards, which conduct by the Health Ethics Commission of Health Polytechnic of Jakarta I.

The research design used was an experiment. This research was conducted at the Clinical Laboratory of the Dental Nursing Department of the Health Polytechnic Jakarta I on Jl. Wijayakusuma Raya, Cilandak - South Jakarta. The time of the study was carried out from January-December 2018, where the data collection was carried out in November 2018 for 5 (five) consecutive days. The population in this study was a member of the academic community in the Health Polytechnic Jakarta I. The sample were 31 students and employees who had anterior teeth with extrinsic stain, selected by purposive sampling. Before we conducted this research we were very concerned about ethical studies, because in this study the object of the study was humans, although using materials that would be applied to human body tissues in the form of strawberries was safe for consumption. The application of strawberries to the teeth relatively will not cause side effects if the duration is according to the provisions, which is 5 (five) minutes.

The data collected were numerical data so that they were presented descriptively in the form of the mean score $^{(8)}$, then the differences in the scores before and after the treatment are tested using multivariate analysis.

\section{RESULTS}

Descriptive analysis was performed to see changes in the mean Intensity Score, Area Score, and Combined Score before the action was carried out until the day of preparation for maintenance.

Table 1. Extrinsic stain initial score (before treated)

\begin{tabular}{cc}
\hline Lobene Stain Index & $\begin{array}{c}\text { Mean of initial score } \\
(\mathrm{n}=31)\end{array}$ \\
\hline Intensity Score & 22.1 \\
\hline Area Score & 22.7 \\
\hline Combined Score & 22.4 \\
\hline
\end{tabular}

Table 1 shows the mean score of extrinsic stains on the anterior teeth of 31 respondents before they were treated. Mean of Intensity Score was 22.1; Area Score was 22.7; and Combined Score was 22.4.

Strawberry extract at a concentration of $100 \%$ on dental work done during the five (5) consecutive days without a break with 2 calculations. 
Table 2 shows the mean of Intensity Score, Area Score and Combined Score from the 1st day to the 5thday treatment. The mean intensity score decreased gradually from day 1 to 19.9 ; then the second day becomes 14.0; 3rd day to 12.6; the 4th day becomes 11.1; and on the 5th day it became 10.4.

Table 2. Mean of extrinsic stain score on day 1 to day 5 (after-treatment)

\begin{tabular}{cccccc}
\hline \multirow{2}{*}{ Lobene Stain Index } & \multicolumn{5}{c}{ Mean score (day) } \\
\cline { 2 - 6 } & 1 & 2 & 3 & 4 & 5 \\
\hline Intensity Score & 19.9 & 14.0 & 12.6 & 11.1 & 10.4 \\
\hline Area Score & 20.1 & 16.1 & 15.2 & 13.1 & 12.2 \\
\hline Combined Score & 20.0 & 14.6 & 13.9 & 12.1 & 11.3 \\
\hline
\end{tabular}

For the Area Score, the average score decreased to 20.1 on the 1st day, on the 2nd day the score dropped to 16.1 ; 3rd day becomes 15.2 ; 4th day dropped to 13.1 ; and on day 5 the score decreased again to 12.2.

Combined Score which is a combination of the average Intensity Score and Area Score also changes from day 1 to day 5 of treatment. Since day 1 of the treatment the score dropped to 20.0; 2nd day dropped to 14.6; 3rd day becomes 13.9; 4th day to 12.1; and on the 5th day, the score becomes 11.3.

The percentage decrease in extrinsic stain score from day 1 of treatment today 5 is presented in table 3 .

Table 3. The Percentage change of Extrinsic Stain Score

\begin{tabular}{cccccc}
\hline Lobene Stain Index & \multicolumn{5}{c}{ Percentage change in Extrinsic Stain Score (day) } \\
\cline { 2 - 6 } & 1 & 2 & 3 & 4 & 5 \\
\hline Intensity Score & 10.1 & 36.6 & 42.8 & 49.9 & 52.8 \\
\hline Area Score & 11.4 & 29.1 & 33.0 & 42.5 & 46.4 \\
\hline Combined Score & 10.7 & 35.0 & 37.8 & 46.1 & 49.6 \\
\hline
\end{tabular}

From table 2 and table 3 it can be seen that there was a change in the mean and percentage of Intensity Score, Area Score, and Combined Score from the beginning of treatment or the 1st day to the 5th day of the treatment. The mean Intensity Score on day 1 was 19.9 (down 10.1\% from the initial score); then the second day the score dropped to 14.0 (down 36.6\%); 3rd day to 12.6 (down 42.8\%); 4th day to 11.1 (down 49.9\%); and finally on the 5th day to 10.4 (down $52.8 \%$ from the initial score).

For the Area Score, the average score decreased from the beginning to 20.1 (down $11.4 \%$ ) on day 1; on the 2nd day the score dropped to 16.1 (down 29.1\%); 3rd day to 15.2 (down 33.0\%); 4th day down to 13.1 (down 42.5\%); and the fifth day the score decreased again to 12.2 (down 46.4\%).

Combined Score which is a combination of the mean Intensity Score and Area Score also experienced changes from the initial conditions until the 5th day of treatment. Initial measurements obtained a mean score of 22.4 which then declined since day 1 to 20.0 (down 10.7\%); 2nd day fell to 14.6 (35.0\%); 3rd day to 13.9 (down $37.8 \%$ ); 4th day to 12.1 (down $46.1 \%$ ); and on the 5th day the score became 11.3 (down $49.6 \%$ from the initial score).

Multivariate analysis was performed to find out the most effective number of days needed to clean up the extrinsic stain. The significance value in the statistical test was seen to be significantly 0.000 reducing the extrinsic stain score on day 2 to day 5. Multivariate analysis results for the Intensity Score and Area Score can be seen in Table 4 and Table 5. 
Table 4. Significance of decreasing Intensity Scores

\begin{tabular}{|c|c|c|c|c|c|c|}
\hline \multirow{3}{*}{ Intensity } & \multirow{3}{*}{ Mean } & \multirow{3}{*}{$\begin{array}{l}\text { Std. } \\
\text { Error }\end{array}$} & \multicolumn{2}{|c|}{$95 \%$ Confidence } & \multirow{3}{*}{ Sig. } & \multirow{3}{*}{$\begin{array}{c}\% \\
\text { decrease }\end{array}$} \\
\hline & & & \multicolumn{2}{|c|}{ Interval } & & \\
\hline & & & Lower & Upper & & \\
\hline 1 & 22.067 & 2.052 & 17.871 & 26.263 & & \\
\hline 2 & 19.800 & 1.926 & 15.861 & 23.739 & 0.012 & 10 \\
\hline 3 & 14.000 & 1.751 & 10.420 & 17.580 & 0.000 & 37 \\
\hline 4 & 12.333 & 1.751 & 8.751 & 15.915 & 0.000 & 43 \\
\hline 5 & 10.867 & 1.729 & 7.331 & 14.402 & 0.000 & 50 \\
\hline 6 & 10.300 & 1.708 & 6.807 & 13.793 & 0.000 & 53 \\
\hline
\end{tabular}

Table 5. Significance of decreasing Area Scores

\begin{tabular}{|c|c|c|c|c|c|c|}
\hline \multirow[t]{2}{*}{ Area } & \multirow[t]{2}{*}{ Mean } & \multirow{2}{*}{$\begin{array}{l}\text { Std. } \\
\text { Error }\end{array}$} & \multicolumn{2}{|c|}{ 95\% Confidence } & \multirow[t]{2}{*}{ Sig. } & \multirow{2}{*}{$\begin{array}{c}\% \\
\text { decrease }\end{array}$} \\
\hline & & & Lower & Upper & & \\
\hline 1 & 22.600 & 1.958 & 18.596 & 26.604 & & \\
\hline 2 & 20.000 & 2.002 & 15.905 & 24.095 & 0.008 & 11 \\
\hline 3 & 16.100 & 1.861 & 12.294 & 19.906 & 0.000 & 29 \\
\hline 4 & 14.933 & 1.955 & 10.934 & 18.932 & 0.000 & 33 \\
\hline 5 & 12.867 & 1.922 & 8.935 & 16.799 & 0.000 & 42 \\
\hline 6 & 12.033 & 1.937 & 8.071 & 15.995 & 0.000 & 46 \\
\hline
\end{tabular}

The decrease in Intensity Score and Area Score can be seen in Figure 1 and Figure 2. It can be seen that the mean Intensity Score had decreased sharply on the 2nd day and then thereafter the horizontal tendency on the 3 rd day to the 5th day. For the Area Score, the graph shows a sharp decrease in score since day 1 and 2, and then the following day tends to decrease slightly.

From the results of experiments conducted for 5 consecutive days, it can be seen that from day 1 to day 5 there was a significant decrease in extrinsic stain scores, as evidenced by significance levels in the range from 0.012 to 0.000 for intensity and 0.008 to 0.000 for the area. For the percentage of reduction when compared to before treatment, a $10.1 \%$ decrease was obtained on the 1 st day, reaching $52.8 \%$ on the 5 th day for the Intensity Score, while for the Area Score there was a decrease of $11.4 \%$ on the first day -1 to reach $46.4 \%$ on the 5 th day.

It can be seen that the mean Intensity Score had decreased sharply on the 2nd day and then thereafter the horizontal tendency on the 3rd day to the 5th day. For the Area Score, the graph shows a sharp decrease in score since day 1 and 2, and then the following day tends to decrease slightly.

From the results of experiments conducted for 5 consecutive days, it can be seen that from day 1 to day 5 there was a significant decrease in extrinsic stain scores, as evidenced by significance levels in the range from 0.012 to 0.000 for intensity and 0.008 to 0.000 for the area. For the percentage of reduction when compared to before treatment, a $10.1 \%$ decrease was obtained on the 1 st day, reaching $52.8 \%$ on the 5 th day for the Intensity Score, while for the Area Score there was a decrease of $11.4 \%$ on the first day -1 to reach $46.4 \%$ on the 5 th day.

From 31 respondents who were treated, there were 5 people who did not need until the 5th day of treatment. On the measurement of the score on the 2 nd day there was 1 respondent whose extrinsic stain score had reached 0 , on the 3rd-day measurement there was 1 respondent with a score $=0$, and on the measurement, on the 4th day there were 3 respondents with a score $=0$. 


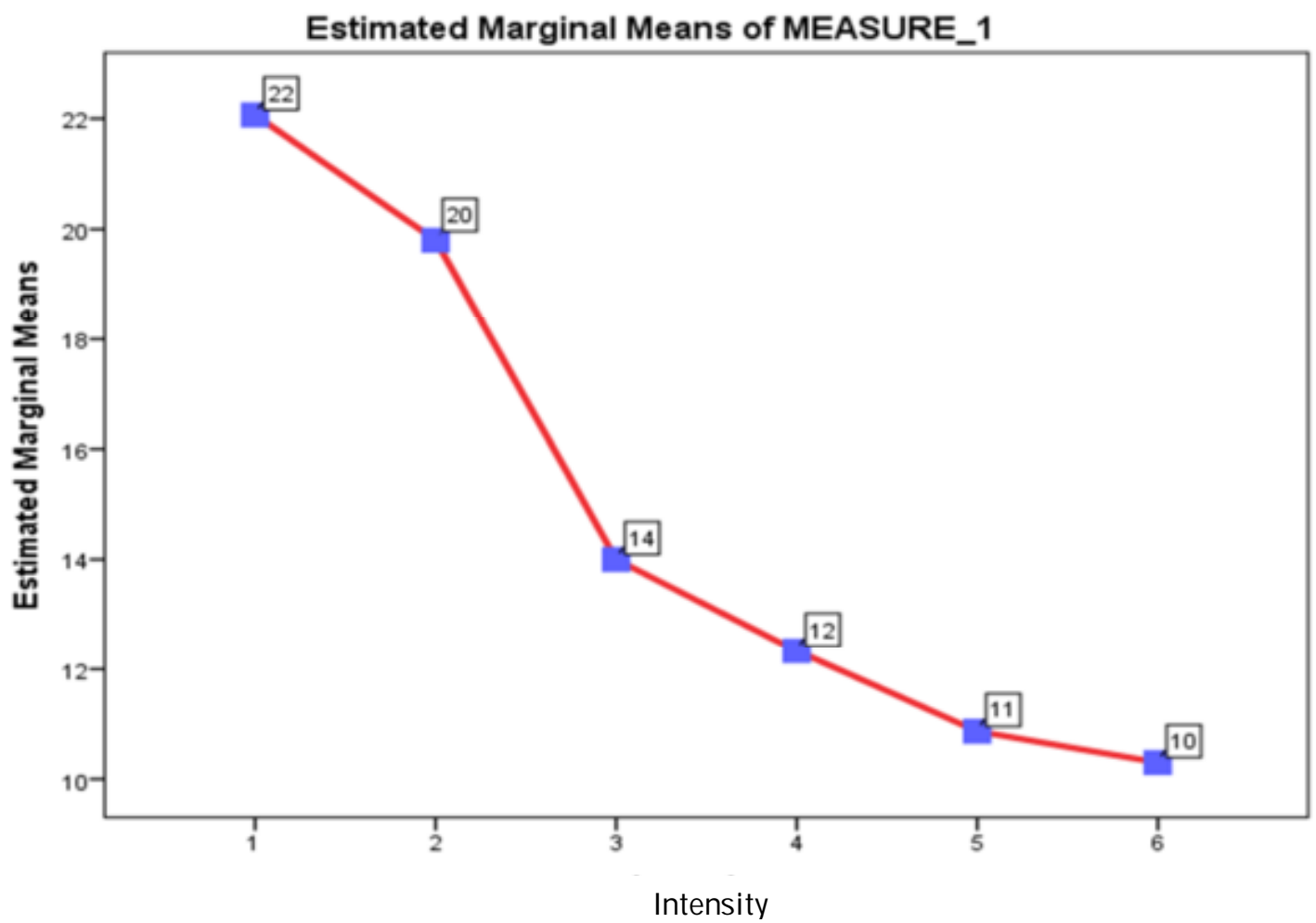

Figure 1. Graph of decrease in Intensity Scores of days 1 through day 5

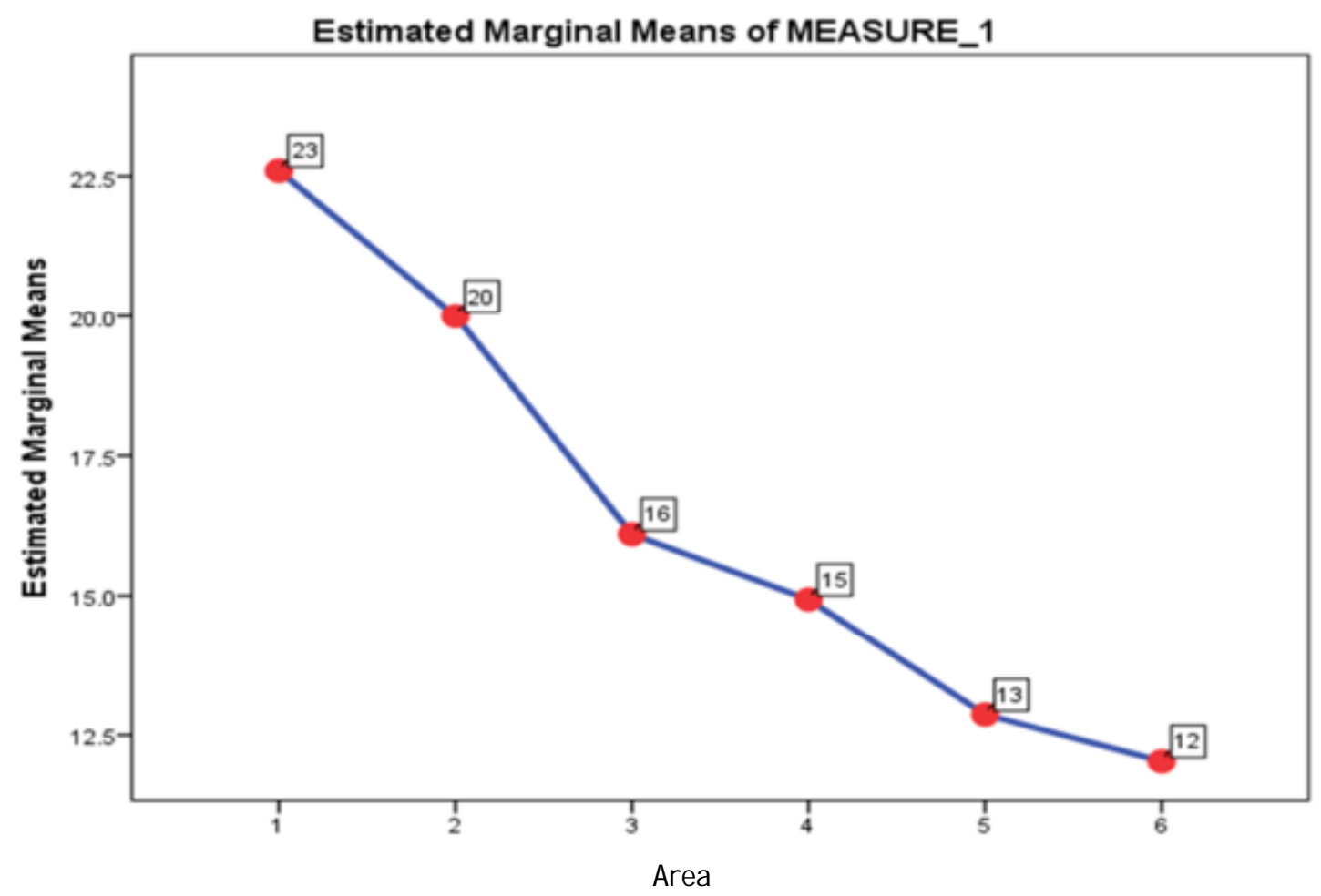

Figure 2. Graph of decrease in Area Score of days 1 to day 5 treatment

202 | Publisher: Humanistic Network for Science and Technology 


\section{DISCUSSION}

The analysis showed that there was a decrease in the stain index both on the Intensity Score and the Area Score from day 1 of treatment to day 5, which in turn also reduced the Combined Score. This is in line with previous research conducted by Karmawati, et al. ${ }^{(7)}$, in which the application of strawberry fruit luminaires conducted for 5 consecutive days can significantly reduce stain scores.

The biggest percentage decrease in stain score occurred on the 2 nd day. For Intensity Scores, the percentage decreased from the initial score from $10.1 \%$ on the 1 st day to $36.6 \%$ on the 2 nd day, while the Area Score from $11.4 \%$ on the 1 st day to $29.1 \%$ on the 2 nd day. For the 3rd day until the 5th day the score decrease was not too sharp although there was still a decrease.

From the results of the treatment of respondents with an initial score for Intensity which has ranged from 4 - 10 and the initial score for Area in a range from $4-19$, extrinsic stain can be completely cleaned using strawberry extract until it reaches a score of 0 for both Intensity and Area.

In this study, there were no side effects such as pain that were complained by the respondents, so it can be suspected that the acidity of the strawberry extract was not as high as that of strawberry fruit as happened in the research of Karmawati, et al. ${ }^{(7,9,10)}$ However, this still needs to be done with further research on the acidity and content of active substances from strawberries that can dissolve minerals in the enamel structure so that it can cause pain (hypersensitivity).

\section{CONCLUSION}

This study is a continuation of several previous studies with the same research focuses on the effects of strawberries in cleaning teeth from extrinsic stain. Strengthening the results of previous studies, this study provides significant results about the benefits of strawberries.

Decrease in extrinsic stain score can be seen from the first day of treatment, and decreases continuously until the 5th day, but the biggest decrease occurred on the 2nd day with a percentage decrease in the Combined Score reaching $35 \%$ when compared with the initial score.

The effect of strawberry extract with a concentration of $100 \%$ on the loss of extrinsic stain does not even take up to 5 days of treatment for some respondents, because the staining score of the respondent has reached 0 before the 5th day. It can be concluded that the extract of strawberries with a concentration of $100 \%$ can clean up extrinsic stain on teeth effectively within 2 to 4 days.

It is hoped that these results can be used as supporting data for further research in the future, which is conducting research in order to find the most appropriate preparation for using strawberries as a tooth stain cleaner. Further research on the side effects of strawberries in such as pain due to the content of active substances in it, can be taken into consideration to do. Besides that, the same research model can be carried out with different variables or different methods to be able to find material/ingredients/drugs sourced from natural ingredients.

\section{Acknowledgments}

Thanks to Dr. Nursama Heru A, S.Si, M.Si, as a consultant of Research Program; drg. Nita Ngatemi, MKM, as Chairman of Dental Nursing Department of Poltekkes Kemenkes Jakarta I; Dr. drg. Jusuf Kristianto, MM, M.Kes as the Head of Research Unit of Poltekkes Kemenkes Jakarta I and the entire staff who have helped in this study; and at last to 3rd Semester's Students of Dental Nursing Department on Academic Year 2017-2018 who have helped on data collection.

\section{REFERENCES}

1. He T, et al. A randomized clinical study to assess the extrinsic staining profiles of stannous- And triclosancontaining dentifrices. American Journal of Dentistry. 2010;23(Special Issue B):1-5.

2. Kwon SR, et al. Systematic review of in vitro studies evaluating tooth whitening. Am J Dent. 2020;33:1724.

3. Gunawan HA. The effect of carbamide peroxide teeth whitening agent on the oral mucosa microscopically: study on LMR strain Wistar rats (Pengaruh bahan pemutih gigi karbamid peroksida terhadap mukosa rongga mulut secara mikroskopik: penelitian pada tikus wistar strain LMR). Jurnal Kedokteran Gigi Universitas Indonesia (Journal of Dentistry Indonesia). 2003;10(EK):652-656.

4. Sharfina G, Gunawan HA, Redjeki S. The comparison of color space systems analysis on enamel whitening with infusion extracts of strawberry leaves. Journal of International Dental and Medical Research. 2018;11(3):1011-1017. 
5. Adawiyah R. The effect of strawberries in whitening the surface of teeth discolored by coffee (Efek buah strawberry dalam memutihkan permukaan gigi yang mengalami diskolorasi oleh kopi). Undergraduate Thesis. Jakarta: FKG-UI; 2004.

6. Karmawati IA, Yulita I, Budiarti R. Effect of strawberries on discoloration of teeth undergoing extrinsic stain (Pengaruh buah stroberi terhadap perubahan warna gigi yang mengalami extrinsic stain). Jakarta: Poltekkes Kemenkes Jakarta I; 2014.

7. Karmawati IA, Budiarti R, Yulita I. The influence of strawberries on the cleaning of teeth with extrinsic stain in the Academic Community of Poltekkes Kemenkes Jakarta I (Pengaruh buah stroberi terhadap pembersihan gigi dengan extrinsic stain pada civitas akademika Poltekkes Kemenkes Jakarta I). Jakarta: Poltekkes Kemenkes Jakarta I; 2015.

8. Nugroho HSW. Descriptive data analysis for numerical data (Analisis data secara deskriptif untuk data numerik). Ponorogo: FORIKES; 2014.

9. Karmawati IA, Yulita I. The effect of strawberry on color changing of tooth with extrinsic stain. Jakarta: Faculty of Dentistry UI; 2016.

10. Yulita I, Karmawati IA, Budiarti R. Strawberry extract as a tooth stain remover. Health Notions. 2019;3(1):28-31. 